\title{
Timothy Grass Pollen IgA Measurement
}

National Cancer Institute

\section{Source}

National Cancer Institute. Timothy Grass Pollen IgA Measurement. NCI Thesaurus. Code C130089.

A measurement of the Timothy grass (Phleum pretense) pollen IgA in a biological specimen. 